\title{
Arrested Motion and Future-Mourning: Hybridity and Creativity
}

Brian Castro

\section{(2) OpenEdition}

\section{Journals}

Electronic version

URL: http://journals.openedition.org/transtexts/253

DOI: $10.4000 /$ transtexts.253

ISSN: 2105-2549

Publisher

Gregory B. Lee

Printed version

Date of publication: 1 December 2008

Number of pages: 83-99

ISSN: 1771-2084

\section{Electronic reference}

Brian Castro, «Arrested Motion and Future-Mourning: Hybridity and Creativity », Transtext(e)s

Transcultures 跨文本跨文化 [Online], 4 | 2008, Online since 15 October 2009, connection on 03 May

2019. URL : http://journals.openedition.org/transtexts/253 ; DOI : 10.4000/transtexts.253

(c) Tous droits réservés 


\title{
Arrested Motion and Future-Mourning: Hybridity and Creativity
}

\author{
BRIAN CASTRO
}

\begin{abstract}
Melancholy seems always to have had a bad press. In this essay I explore the ways in which the expression of negativity, ambivalence and dissonance in melancholy influenced and shaped my writing. Much of this melancholia stemmed from transplantation and dissonance and from the need to make oneself heard in a host country whose blindness to alterity ran parallel to an identitarian politics framed by exclusion. When a nation is unable to mourn its history, writers tend to be paralysed, being unable to detach themselves from a nation-building canon. I investigate melancholia as a productive agent in employing critique to produce countertraditions and to offer resistance to dominant ideologies. I focus on writing in order to explore distinctive moments when melancholia, expressed in forms ranging from dissimulation to irony, played a decisive role in my writing career.
\end{abstract}

1991 was not a very good year for me. I had written two novels in eight years and was staring down the barrel of failure. I was living in a small cabin in the Blue Mountains with the curtains drawn and a shotgun by my bed. I was reading Samuel Beckett's trilogy Molloy, Malone Dies, The Unnameable, and I still have that copy with me today. Most of the pages have fallen out with re-reading. Beckett said when he finished writing the last line of a book he went to bed for four months. I had just completed a novel and I didn't know if it was any good. It was called Double-Wolf. I didn't feel any sense of triumph. I felt folded. Doubled. Nobody was going to get it. I went to bed. The first line in Beckett's Malone Dies goes like this: I shall soon be quite dead at last in spite of all. 
This was what I wrote in my diary:

“Thursday, 29 August 1991. Time: 11:54am

I shall spite all or soon be quite dead. Patrick White said Sidney Nolan 'had it in him' to overcome despair. I've got to have it too. The writing came in a rush. Now it's gone. Nobody will ever get it in Australia. Nobody ever does. They want a national canvas but I have an anarchic soul: nothing inspires me more than difficulty and suffering, fear and loathing. Without them a writer is dead. Without spleen you cannot overcome despair. I shall spite all or soon be quite dead.

Thursday, 29 August 1991. Time: 1:28pm

Listening to Mendelssohn. Calmer now. There's a rhythm to passions. Outside the wind is raging and trees are cracking. It is probably snowing in Vienna. How I love this writing life!"

The diary ends there. The rest of the pages are blank. I felt I had come out of nowhere and was going nowhere. But there was some humour in my arrested motion. I was everywhere in my writing. All over the place.

As a writer in Australia, I have always been conscious of the mark of lineage. My influences have always been from elsewhere, but my experiences are Australian. I don't mean that in a nationalistic sense, because I am very much an anti-nationalist. My work was once described as "having no precedence in Australia." Originally I took this as praise, but soon realised this was meant as the opposite. I have been described as a hybrid writer, a fusion fictionist, a multi-ethnic mélange. Since authenticity was everything, I had always found refuge in impersonation. This false life, which had obviously turned me into a writer, allowed me to entertain multiple cultural perspectives. It gave me an alternative in a country where literary identity was premised upon birthright, land and landscape; the presumed poetic ownership which whitewashed the lineage of violent appropriation and the penal origins of white settlement. Imposture, therefore, may have granted me an empathy with besieged mentalities. For besieged mentalities exaggerate wildly.

Exaggeration - Rabelais is one example - enabled a novelist to force the suspension of moral judgment. As Milan Kundera wrote: "Suspending moral judgment is not the immorality of the novel; it is its morality." This is why the arts are so important; because they create an environment in which we can understand the truths of others. Without understanding and awareness, there is only disapproval and censorship. So impersonation for me coerced a reinvention of the self, forced open new perspectives, but it also played a prophylactic part, warding off despondency. This double life permitted the practice of a dialectic. A troubled identity. And a 
troubled identity may be the best way of resolving conflict in the modern world. In staging opposite positions under one roof in a state of melancholic immersion, it can turn passive depression into productive critique. So while I see myself as an Australian novelist with a small ' $a$ ', I do not feel I represent the linear inheritance of national feeling, particularly of land and landscape; blood and soil; propriety and tradition. What I can do is to worry the future into possibility.

There is little doubt that I have become a writer of contradiction. On the one hand, I stage a condition which doubts its own authenticity; consequently many of my protagonists are hybrids of one sort or another. On the other, I am critiquing righteousness, which is an artifice that masks the barbarities of civilization. This ambiguous position is not only troublesomely illogical, but it is also threatening. It may explode into hyperbole or drown in allegory. This is the classic position of hybridity; it is above all, a lexical hybridity, both acerbic and melancholic; hyperbolic and self-ironic. Inside and outside the laws of grammar and of society.

I can think of no one better to express this hyperbolic state than the Austrian writer Thomas Bernhard. In his novel Extinction, he writes that:

"I've always found gratification in my fanatical faith in exaggeration [...] On occasion I transform this fanatical faith in exaggeration into an art, when it offers the only way out of my mental misery, my spiritual malaise. I've cultivated the art of exaggeration to such a pitch that I can call myself the greatest exponent of the art that I know of. I know of none greater. No one has carried the art of exaggeration to such extremes $[\ldots]$ and if I were suddenly asked to say what I really was, secretly, I'd have to say that I was the greatest artist I knew in the field of exaggeration. The art of exaggeration [...] is the art of tiding oneself over existence, of making one's existence endurable, even possible." ${ }^{1}$

It is this hyperbolic mode that has enabled Bernhard to scathingly describe Austrian society in these terms, again, in the voice of his narrator:

"Genius and Austria do not go together, I said. In Austria one has to be mediocre in order to be listened to and taken seriously, one has to be a person of incompetence and of provincial mendacity, a person with an absolute smallcountry mentality. A genius or even an exceptional mind is sooner or later finished off here in a humiliating manner..." 2

Even though it occurs inside a novel, it would be difficult to imagine any Australian author writing this kind of splenetic attack on his own country other than Patrick

\footnotetext{
1 Thomas Bernhard, Extinction, New York, Alfred A. Knopf, 1995, p. 307.

2 Thomas Bernhard, Old Masters, [trans. Ewald Osers], Chicago, The University of Chicago Press, 1992, p. 8.
} 
White. It would be interesting to ask how a national literature recycles allegiances. How melancholy and spleen might offset this desperate patriotism to allow a vibrant criticality.

When I first began writing, I thought melancholic exaggeration was my own secret practice. But then I read Kierkegaard. In his book The Point of View for my Work as an Author, he wrote:

"From a child I was under the sway of a prodigious melancholy, the depth of which finds its only adequate measure in the equally prodigious dexterity I possessed of hiding it under an apparent gaiety and joie de vivre. So far back as I can barely remember, my own joy was that nobody could discover how unhappy I felt." ${ }^{3}$

I think it is quite obvious that Kierkegaard's melancholy was an inwardness which concealed its truthfulness through dissimulation. By trying to deceive himself through jokes and impersonations (he was an inveterate pseudonymous pamphleteer for example), he found solitude in his sadness, a state that was continually challenged by the excitement of literary experimentation. Since melancholy could never be represented, because it is an irrational disposition, I think it is possible to say that this kind of sadness can also be creative if you know you're fooling yourself into some kind of aesthetic posture which inscribes a truth. There is a normative element in this and I don't think I'm stretching a point by saying that the solitude of creative sadness organises a community of feeling which knows how to read between the lines and is sympathetic to what I call the reading posture. Without being confessive, a writer adopts a voice. Without seeking selfreference, a reader puts on a mask of curiosity. All this masking is a form of posturing, but it is also a civic disposition ... a hermeneutic mode of relating to the world which offers the reader a liberation from quotidian and instrumental reason. The erection of disbelief, of judgment, of the righteousness of authenticity ... all of this blurs art and life and neglects playfulness. The recognition of play, of humour, the awareness of another's awareness, the understanding of breadth and the astonishment of liberation ... these are essential in reading. I think every writer has to build this kind of community of awareness, and for a hybrid writer ... I mean that in more ways than one ... for a writer who is vehemently against the imprisonment of genre, which sometimes can provide a crutch for a lack of awareness ... this constituency is invaluable.

In a civil society, the social world should be constitutive of the self. How we feel about ourselves is only the beginning of how we try to encounter others. By

${ }^{3}$ Søren Kierkegaard, The Point of View for my Work as an Author, [trans. Walter Lowrie], New York, 1962, p. 76. 
suspending suspicion and incredulity, there is a trade in illusion. Playfulness allows us to be complicit rather than confrontational. "The proper aim of art", as Oscar Wilde said, was lying ... "the telling of beautiful untrue things." ${ }^{4}$ As Wayne C. Booth has pointed out, Wilde is not disparaging ethics. His aim, Booth writes, "is to create a better kind of person - the kind who will look at the world and at art in a superior way and conduct life accordingly." 5 This trade in counterfeit prepares the ground for a possible unmasking of rhetorical sincerity, authenticity and identity.

In his book Liquid Love, Zygmunt Bauman comments upon the disappearance of the mask, a disintegration of impersonal ties and bonds leading to self-knowledge. By stripping off this layer of sophistication, commitment and value are both sacrificed to the temporary and to the sensational. Where once there was the art of civility, of 'wearing the mask', of impersonation for the sake of objective discursiveness without becoming excessively familiar, there now is the brevity of compulsive confession. ${ }^{6}$ Bauman writes that:

"The 'communities of sameness', predetermined but waiting to be revealed and filled with substance, are giving way to 'communities of occasion', expected to selfcompose around events, idols, panics or fashions ... They last no longer than the emotions that keep them in the focus of attention ... We belong to talking, not to what is talked about."7

The contemporary social condition is not made up of a semi-permanent community of understanding but it seeks brief, seemingly 'authentic' encounters. It requires a 'confidence-deposit', an identity branding, and then it moves on to the next situation. In other words ... if I read Bauman correctly ... there are no more civil and complex postures, but there is a great production of democratic chatter. According to Susan Sontag, what passes for culture at the moment is effectively erasing the prophetic, the critical, the ironic and the subversive. It doesn't allow for the insecurity or gloom from which the prophetic emerges. And it is important to keep in mind that the oracular and the visionary have always emerged from real, rather than imagined insecurity. All the more important then, to make a case for being troubled. The evolution of consciousness from Homeric externality to the modern subjective sensibility, for example, took place through a succession of wars, asylum-

\footnotetext{
4 "The Decay of Lying", in Richard Ellmann [ed.], The Artist as Critic: Critical Writings of Oscar Wilde, Chicago, 1982, p. 320.

5 Wayne C. Booth, The Company We Keep: An Ethics of Fiction, Berkeley, University of California Press, 1988, p. 11.

${ }^{6}$ Zygmunt Bauman, Liquid Love, Cambridge, Polity Press, 2003, p. 12.

7 Bauman, p. 34.
} 
seeking and displacements. ${ }^{8}$

Visiting Kuala Lumpur recently, I had dinner with my Malay translator. Malaysia was in deep turmoil over its racial practices. People were ready to demonstrate; some in a violent fashion. The wounds of the past could not be healed and kept reopening. And it was necessary to do so in order to cauterize them through a recognition of them. During the course of dinner, my translator gave his impressions of Australians. "They appeared so much like wounded animals", he said. I thought this phrase quite apt. To be unaware of one's 'woundedness' is to repress melancholy, regarding it as 'unmanly'. The representation of Australian melancholy, which is obvious in its ritualistic celebrations of war-sacrifice and battles with nature, distinguishes itself by erasing the Other. Australian writing is layered with this inability to mourn others while glamorizing death as a concept. Social patriarchy lays an empty place at the head of the table for courage but not for mourning. It is therefore not uncommon to find so much mainstream Australian literature settling for realism and ordinariness as factors of 'honesty' and selfmastery. Whilst these can be sentimentalised, they cannot be intellectualised. So in Australian literature there are countless mythologies of flawed men and women who transact mysteries with indigenous peoples and with Nature in order to find salvation through a recuperation of innocence. This enthusiasm for nativism is in effect a subconscious re-appropriation of equality where there is none. The power of the primitive urges readers to admire characters who can thumb their noses at European sophistication ... realism as a form of national legitimation. Simply to represent this re-adjustment is often considered to be holding the higher moral ground. It is why writers like myself fall into the too-hard basket. I've often been described as 'difficult', but only because I do not share the generic taxonomy of Australianness in its identifiably sentimental tradition, by enthusiastically embracing the ambiguities and parodies of literary Modernism.

When one rewrites the past, one excuses the present. As Amartya Sen pointed out, it is a "conceptual disarray, and not just nasty intentions" ... which has contributed to "the turmoil and barbarity we see around us." 9 This conceptual disarray is a misunderstanding of history and a reduction of complexity. The reduction of history to politics has had a long tradition in many countries. Like the phrase 'the clash of civilizations' the conceptual reduction of diverse identities to a national identity has contributed more to conflict than to understanding. Barbarism it seems, is never at home, but is always knocking at the door outside. Indeed,

\footnotetext{
8 See Julian Jaynes, The Origin of Consciousness in the Breakdown of the Bicameral Mind, Boston, Houghton Mifflin, 1976.

${ }_{9}^{9}$ Amartya Sen, Identity and Violence, NewYork, W.W. Norton, 2006, p. xiv.
} 
etymologically 'barbarism' derives from the word babble, the sounds which foreigners make. And while many Australians may not think of themselves as particularly barbaric, they are also unaware that they live in one of the most regulated countries in the developed world. It makes itself foreign to others. During moments of its history it has been an island of paranoia, entrenching itself as monolingual, racist and parochial. Over the last decade for example, it has been institutionally punitive against non-whites: asylum seekers, indigenous Australians and down-at-heel immigrants. This may not sound too barbaric, but at the level of institutional control and bureaucratic babble, these instruments of cruelty in the name of identity and security have been more effective than cudgels. There was no further level of appeal for people wronged in this system.

Take the case of Vivian Alvarez Solon. Seriously injured in a car accident, this Australian citizen was listed by the Queensland Police as a suspicious illegal immigrant. This woman, who held an Australian passport, but wasn't able to produce it, was taken to a hospital, then held in a detention centre and then deported to the Philippines. Confused, suffering mental illness, she was discovered by a priest four years later. She was living in filthy conditions in Manila. When her case was made known, the then Immigration Minister Amanda Vandstone, commented: "There's a woman who was clearly in need of help and who through, I think it's fair to say, no fault of her own ended up in an immigration detention facility and clearly didn't have the capacity to explain to people who she was."

Fairness, it seems, is built into the notion of forgetting. Vivian Alvarez Solon genuinely forgot her identity. She is fluent in three languages and will probably write her memoirs.

I think hybrid writers ... and here I don't only mean writers with a different skin, but writers who do not conform, either generically or canonically ... I think these 'non-national' writers suffer the same suspicion about their authenticity. They've somehow misplaced their passports in the national mythology. They are suspect and 'illegal'; lost in their labels and puzzling in their negativity. They trouble rather than entertain. They do not console. In a literary culture they would be the norm. But a whole range of perceptions once made available through reading within a humanistic education has been degraded by economic policies. In universities throughout Australia, deep thinkers and critics upon whom such writers had been relying have been turned into marketeers and petty bureaucrats. Bookscan, the statistical website monitoring book sales, has become the measurement of culture. Such corporatisations of the imagination stipulate that thinking about oneself should be neither gloomy nor rhetorical; just quantitative. They declare that writers have never had it so good. This enforced cheerfulness has always been historically 
driven. The 'gloom thesis' in Australian cultural critique holds the view that melancholics belong to an élite, that they retard material national progress. Melancholics, so this thesis goes, dwell in the luxury of complaint, living a life equivalent to aristocratic boredom. This position, which is both radical nationalist and conservatively bourgeois, devalues gloom, since gloom threatens national solidarity and is non-productive. Critique of nationalism therefore, has been corralled into complaint.

Social critic Wolf Lepenies points out in his book Melancholy and Society, ${ }^{10}$ that while gloom carries an 'élitist' claim, it is also a cultural critique which makes a claim for subtlety and turns against itself in a constant dialectic. ${ }^{11}$ As Lepenies notes: "The élitist claim and the pathos of the special are combined with retrospection and with the dignity that draws its glory from dedication and sacrifice." 12 The "pathos of the special' is why writers are writers. It is special because the struggle is not rewarded, at least in an artistic sense. The gesture is extravagant and its vulnerability is deep. If writers were sincere and authentic they would have no other selves, and would risk falling into stridency, sentimentality or esotericism. But good writers are always characters-in-progress, a field of selves which can be drawn on for social reflection. This loss of a singular identity and along with it, authorial sincerity, is a gain for others. But the residue for the writer is melancholia. Melancholy finds a space in which to suffer. It is dignified because it cannot be displayed. To enjoy any kind of display as a writer would be to risk the depreciation of one's writing; to lose its force. Baudelaire, for example, would not be Baudelaire if he had the same laurels bestowed upon him as they were bestowed upon Victor Hugo.

The black bile which rages against acceptance is the result of a wound. A wound, when examined self-reflectively, is self-inflicted; it cannot call for pity or special pleading. As Edward Said wrote, learned protest only works if the "exile refuses to sit on the sidelines nursing a wound ... there are things to be learned: he or she must cultivate a scrupulous (not indulgent or sulky) subjectivity." 13 A wound is not revenge or a working through. It is not about stoicism or endurance. It is not about the seniority of suffering or the triumphs of fame. As Lepenies says, this wound that is melancholia stands against Enlightenment optimism, forfeiting 'the Enlightenment impulse to improve the world'. ${ }^{14}$ Since this wound can never honour its suffering, its disposition is inertia. But it has value in generating rebellion and

\footnotetext{
10 Wolf Lepenies, Melancholy and Society, [trans. Jeremy Gaines and Doris Jones], Massachusetts, Harvard University Press, 1992.

11 Lepenies, p. 194.

12 Lepenies, p. 196.

${ }^{13}$ Eward Said, Freud and the Non-European, London, Verso, 2003, p. 3.

${ }^{14}$ Lepenies, p. 197.
} 
critique by menacing purity, canons, happiness, all of which are forms of forgetting. The wound is the knot in the handkerchief, mindful of the illogic of the outside world. A memorial ligature tied to vision.

You know the ancient Greek story. Philoctetes had a bow that would never miss its mark when firing an arrow. But he also had a wound that would never heal. I think this is the condition of the melancholic hybrid writer. It is what Jacqueline Rose called a 'broken identity.'15 The way, for instance, that Freud distanced himself from his own Jewishness in order to universalize it was to enact a broken identity in pursuit of a vision. This was a long way from identity politics; light years from personal empowerment. As Rose said, you read a writer:

"[...] not for what they failed to see, not for the ideological blindspots of their writing - too easy, too programmatic in the literary academy of recent years but for the as-yet-unlived, still-shaping history which their vision - partially, tentatively, foresees and provokes. The task of such a reading [in Edward Said's words] is to 'dramatize the latencies in a prior figure or form that suddenly illuminate the present.'"'16

I would like to suggest that this is what the hybrid has to offer: the time of reflection which provokes vision out of the trauma of being torn. Without losing sight of the dual propensities of melancholy for paralysis and for productive creativity, the hybrid's mourning for the loss of authenticity originally encourages the subject to hide inside his or her wound. From this, creativity is coerced. It was Abraham and Torok, ${ }^{17}$ who first made the distinction between incorporation and introjection. Incorporation is where psychic functioning responds to trauma by substituting blockage, stasis and paralysis for expression. Introjection is the process of accepting the wound, taking in loss, transforming it and translating it into something new. In this 'creative melancholy' exhilaration and the abyss exist side by side.

In January of 1961, at the age of ten, I was sent by myself from Hong Kong, to Australia, to boarding school. My father had calculated that there was going to be a war between China and America. In the plane I read a book my grandmother had given me. It was called Britain And Her Neighbours. Well, it's a fact that my grandmother was from Liverpool and that she was a Baptist missionary in China between 1913 and 1926. It's a fact that she married a Chinese man, a landowner who financed her projects. It's a fact that my grandmother became the principal of a girls'

\footnotetext{
${ }^{15}$ Jacqueline Rose, "Response to Edward Said", in Freud and the Non-European, London, Verso, 2004, p. 70.

${ }^{16}$ Rose, p. 67.

17 Abraham, Nicolas and Maria Torok, The Shell And The Kernel: Renewals Of Psychoanalysis. [Ed., trans., and intro. by Nicholas T. Rand], Chicago, University of Chicago Press, 1994.
} 
school in Hong Kong and started up girls-only schools all over China, since girls were the most disadvantaged people, particularly in rural Chinese communities. It's a fact that when I visited Liverpool many years ago, there was a memorable scene. I saw a family emptying some ashes from an urn into the Mersey. The wind blew the ashes back. A few minutes later, as if on cue, they all took out their combs. My memories of loss were not about facts. They were about wounds. But out of these, I was making the melancholic profit which gave me my writing.

I remember playing in my grandmother's school. I was probably nine at the time. I was hiding in the locker-room next to the basketball courts. There was a janitor; a black man. He was stacking chairs in the gymnasium and he was removing chewing gum stuck to the floor, peeling it off with an ivory comb. There was music coming from a wind-up gramophone. Later, I saw my grandmother teaching him how to waltz. I'm not sure if I made up the idea of the ivory comb. Once upon a time I was told there was a famous African writer by the name of Ndebele. I liked that name. 'I saw Granny dancing with Mr. Underbelly', I said to my mother. I remember my mother threatening me with a feather-duster for suggesting such a thing. But this would have made what I had said significant, so perhaps the incident was true. In writing about it in my novel Shanghai Dancing, I would have my grandmother and the janitor conduct a shipboard romance when the ship sailed for Liverpool ... all by implication rather than by actually narrating it. They waltzed together on deck while the disastrous lives of their family members unfolded. Can you imagine a shipboard romance in the 1950s between an English woman and an African man on a voyage to Liverpool?

I later found out there was no famous African writer by the name of Ndebele. So the narrator is an unreliable narrator, but his fetish for certain objects should alert one to the uncanny nature of how the dead reassert themselves in memory. My grandmother was blind. Before she died, she laid out all her precious things on the bed next to her. She passed her fingers over each one. They were mostly old books. Oh yes, and there was an ivory comb.

Freud said something interesting about memory. He said that the memories least likely to be recorded are the most significant ones, and they are significant because they are least interesting. Even today I'm still haunted by that comb, because the janitor was completely bald. By hiding what was significant in what seemed least interesting, rather than pointing it out because it appeared significant, I hoped to allow the reader to reconstruct meaning in the gaps between my grandmother, Mr. Ndebele, Hong Kong and Liverpool. My vision of writing was formed not from a cultural romanticism but from despondency and a yearning for a place elsewhere. This homelessness was not a mourning for the past or for a utopia, but a 
melancholic design: a safe-keeping not so much of beauty but of loss. As long as this remains, literature will remain, for in my mind, literature is the linguistic recuperation of a suffering sensibility situated in the interstices of two different worlds; one which is real and one which is impossible.

While the past cannot be changed and mourning cannot be accomplished - because in Australia, melancholy is continuously being warded off as weakness - that is, there is no conceptual construction of the lost thing - one should consider the possibilities and rewards of a future-mourning. Future-mourning means being equipped with vision, just as doom-saying has always been an important part of every culture. In 1907, Otto Gross married the idea of neurotic negativism with Freud's idea of unconscious repression. What Gross was saying was what writers throughout the ages have always been doing: telling stories with a good deal of negative content in order to release the repressions of the individual to connect with a wider cast of internal characters. These other selves destabilise the present and through the loss of authenticity, are liberated into generating apocalyptic visions. As Maurice Blanchot noted, this "farewell given ahead of time" delivers a "boundless insecurity". ${ }^{18}$ It is the insecurity of being which provides poetry for example, with its Orphic or oracular qualities. A broken or troubled identity can be productive of vision, providing you have the ability to fool yourself into blindness first. You just don't know what you're going to foresee until you write it. Too much self-consciousness and the game is up. To much manipulation and the authentic, authoritarian self returns to put an end to your writing day.

I have always had the ability to fool myself. As a child, I became short-sighted quite suddenly. It was the result of an illness, combined with reading too much in bed. I used to invent things that others couldn't see: giant water buffalo grazing amongst sky-scrapers in the hills above Hong Kong; a bejeweled Rolex watch projected onto the night sky; gleaming angels arriving at dawn for Christmas. These diversions transformed my quotidian experience of depression, turning it from inexpressibility to invention and intervention. I think I learned early on that invention was intervention. You changed yourself and others by thinking differently; not in the realms of fantasy but always straying closer and closer to reality; always near to possibility. The thing was that some of my fanciful sightings were quite accurate. An eccentric Hong Kong billionaire did scoop out terraces on the hillside next to his villa and imported a water buffalo. One of the jewels in the Rolex watch turned out to be a Russian Sputnik traversing the night sky. A large stone angel was lowered by a crane at midnight onto the top of a church near my house, some five months after I had first invented it. Even my parents were impressed. My friends queued

${ }_{18}$ Maurice Blanchot, L'espace littéraire, Paris, Gallimard, folio/essais, 1994, p. 205. 
up to have their fortunes told.

It was the philosopher Gaston Bachelard who said that:

"[The imagination] will have visions if it is educated through reveries before being educated by experiences, if experience follows as affirmation of its reveries." 19

In my case, extreme short-sightedness challenged the imagination to store up signs, a process which ultimately produced a kind of parallel universe. But all of this blind talent for speculation and allegory came at the expense of a terrible sadness. Even today, I cannot believe that there can be happy writers. Happy writers are those who have lost the truth of their suffering. It is through disturbance that the future can be glimpsed. The willingness to take on human despondency is essentially the social role of art as well as its insubordination. It says 'no'. It refuses happy endings. Its catharsis is for others. Slavoj Žižek wrote in a recent article that:

"The melancholic's refusal to accomplish the work of mourning ... takes the form of its very opposite, a faked [my italics] spectacle of the excessive, superfluous mourning for an object even before this object is lost." 20

I hasten to point out the fakery. Writers who do not repeat canonical narratives are in the business of staging and anticipating apocalyptic scenarios wherein they mourn for something that is not yet lost. This was always their duty; to test the waters, to place an ear on the ground; not to distance themselves from society but to experience desolation through impersonation and to risk perdition for prevision. This disappointment in never achieving perfection, this perpetual melancholia in encrypting the open secret of failure, is actually the beginning of philosophy. Surely every enlightened society must accommodate some form of negative chafing? The unfulfilled potential of the past, the disappointment in the future: these are essential in the analysis of contemporary cultural symptoms, in order to map the corruption or slippage of a country's symbolic values. The blandness of American happiness, as Eric Wilson pointed out recently, poses a far greater danger to cultural life by destroying this creative melancholia. ${ }^{21}$

So this is my lamentational cycle. Productive sadness depends on waste. It depends on time. It depends on wasting time for quality thinking. The desired object... that is, the great novel, the perfect poem, is no longer wanted by the writer, even if obtained. So there is a constant provisioning of the desire for art. This storehouse of desire is virtual and essential for valuing unattainable perfection. It cannot provide

\footnotetext{
${ }^{19}$ Gaston Bachelard, L'Eau et les Rêves: Essai sur l'imagination de la matière , Paris, Le Livre de Poche, 1994.

${ }^{20}$ Slavoj Žižek, “Melancholy and the Act”, Critical Inquiry, Vol. 26, n 4, Summer 2000, pp. 657-681.

${ }^{21}$ Eric Wilson, The Australian, Higher Education Supplement, February 8, 2008.
} 
happiness. But the gain in all of this is that of previsioning. One sees the end of a life or of a work through such striving; one sees the end of a novel or the pitfalls of a nation. The measure of maturity is to understand that death is inevitable, not to be ignored. As Clive James said, the great blindspot of Americans is that life is such a production that death only enters as a wild card. ${ }^{22}$ It is why writers, whose real subject is themselves, should also strive to be the radars of a society, not only because they sublimate their own personal experiences but because they are driven to make meaning out of historical catastrophe.

Well, where did my melancholy come from? It's probably genetic. But nurture overrides nature. The trouble with migrants is that you're not entitled to criticize. The moment at which one is granted something so lacking in originality as citizenship, is the moment at which immigrants become impotent, forever silent, unable to be heard. The only recourse is to be counterfeit. This is where I find Kierkegaard so inspiring. He was not an immigrant, but he knew how to dissimulate. "I am never entirely who I am", he writes in Fear and Trembling. "My deception is just as cunning as my depression is deep" 23 , he says, justifying why he should not go ahead with his marriage, which like a novel, he already saw providing him with an unhappy ending.

Difference and deep risk have always been characteristic of any real advance in culture and creativity. Kierkegaard was extraordinarily prescient about how modernity - and here we can substitute Post-modernity - kills difference and passion (and difference arrives through passion) - Kierkegaard knew how language, which leads us to the unknown, is destroyed by superficiality. In 1846, he wrote that:

“[...] eventually human speech will become just like the public: pure abstraction - there will no longer be anyone who speaks, but objective reflection will gradually deposit a kind of atmosphere, an abstract noise that will render human speech superfluous, just as machines make workers superfluous." 24

I think those of us familiar with corporate-speak and theoretical jargon will tend to agree. I know that as a novelist, the novel possesses a history of its own, and that perhaps in some languages, in some cultures, that history is already coming to an end. I wonder if V.S. Naipaul was right when he said the modern university had killed literature? Or was he assuming a posture which provoked debate? Milan

\footnotetext{
22 Clive James, "Falter Ego", The New York Times Sunday Book Review, October 7, 2007.

${ }^{23}$ Kierkegaard, Fear and Trembling, [trans. Alastair Hannay], London, Harmondsworth, 1985, p. 196.

24 Two Ages, a review of a novel by Kierkegaard, [trans. Howard V. Hong and Edna H. Hong] in Søren Kierkegaard's Journals and Papers, New Jersey, Princeton, 1978.
} 
Kundera has put it succinctly, but no less apocalyptically:

"A novelist talking about the art of the novel is not a professor giving a discourse from his podium. Imagine him rather as a painter welcoming you into his studio, where you are surrounded by his canvases staring at you from where they lean against the walls. He will talk about himself, but even more about other people, about novels of theirs that he loves and that have a secret presence in his own work. According to his criteria of values, he will again trace out for you the whole past of the novel's history, and in so doing will give you some sense of his own poetics of the novel, one that belongs to him alone and that is therefore, quite naturally, different from that of other writers. So you will feel you are moving in amazement down into History's hold where the novel's future is being decided, is coming into being, taking shape, amid quarrels and conflicts and confrontations." 25

Well, I used to feel that in Australia, these quarrels and conflicts about the novel's future were what drove me to write against authenticity, against the Australian pragmatic, anti-intellectual ordinariness. I issued the challenge of polyphony, or what I shall call polyphonia. I would like to call this art of the fugue, this assemblage of counterpoints and harmonious hybridities, this orchestra of voices, polyphonia not polyphony. Not only multiple, but counterfeit. Not only multicultural, but linguistically invented. Not only polymorphous, but phony. We are threatened not by difference, but by sameness. Hybridity contains us. We are troubled when the monophonic leads us only to the forlornness of our entrenched identity. But we are enlivened when we know that the author knows that we are all trying it on. Is that not where the real novel begins? Did not the real novel begin with fakery, not only between the covers but outside as well, with Defoe, Rabelais, Cervantes, Sterne and Fielding? Not exactly writers of a singular, national story, but digressers, diverters, funambulists and fakers who abandoned authenticity but not plausibility. And did not their prose come with a profound sadness, even at the height of its comedy? Did not their prose come with a melancholy which emerged from speculation about the human condition; from reflections of possible worlds, far from realism and the cynical realism of the politics of the time? Why did they take such risks to endanger their own positions as respected citizens and comfortable burghers? Because they saw the future of the novel as a disruptive force. Less transparent to themselves, they saw experience as less than the imagination. The imagination jeopardized their lives, raced ahead of respect, of authentication, to the point of ignoring the rites of passage which others had to go through.

I think political events in Australia in the 1980s gave me pause to reflect on the

${ }^{25}$ Milan Kundera, The Curtain, [trans. Linda Asher], New York, Harper Collins, 2006, pp. 77-78. 
bankruptcy of the notion of the rites of passage as an assimilative principle. In Australia, a rite of passage was no guarantee of equality. In the 1980s there was a growing anti-Asian rhetoric and barricades were being drawn up in the media and elsewhere. The worst effect of that decade was the absence of the public intellectual voice in Australia. The great Australian 'good' was in not trying to out-think the public. The public was always right, but it did not have a great sense of prevision. It irrationally predicted an Asian invasion, but this now appears relatively benign in contrast to the demonisation visited upon Muslims. This was graphically conveyed in a cartoon in an Australian newspaper which featured a Muslim woman being harassed in the street. Her veil was being torn off. An Asian man stood in the shadows, wiping his brow, murmuring "Whew! The pressure's finally off us!” This cartoon is embedded with layers of stereotypes. While illustrating successive waves of disempowerment, its sympathy lies not in condemnation, but in reinforcing the racial mythology of impotence and effeminacy. Rites of passage in Australia means more of the same. Nobody actually comes through them. My first novel Birds of Passage was not an elegiac response to the suffering of Chinese goldminers in 19th Century Australia, but a rebuttal of their marginality. Their melancholic presence on the Australian landscape was a glaring one, so much so that it had to be made invisible and unexpressed. They had no rights and their passage was described as migratory, bird-like, in an attempt to wipe away their presence. But they left a powerful stain on the white cultural landscape.

After 1984, I could no longer place myself in a continuum of Australian writing; a whole community of feeling and understanding seemed to have suddenly disappeared overnight. The era of incitement had entered Australian life in a way that had never occurred before in my experience. It was not a war-time call for solidarity, but a sanctioned incitement to establish a national identity defined against others. It was at that moment that civility didn't seem to matter anymore. Ethics looked old-fashioned. I read the newspapers with shock and awe. I'm sure many so-called 'Asians' living in Australia and watching the provocations and incitements of the time felt a growing isolation and disaffection. I'm also sure that the former Prime Minister John Howard lost his seat of Bennelong last year not only because he was faced with a popular oppositional candidate, but because Chinese immigrants, who had formed a powerful voting block in his electorate, had long memories.

If the critical, subversive and prophetic qualities of the novelist that Susan Sontag spoke about were to deepen or to oppose the common understandings of our fate, then we have to take more account of the use of literary language. Non-nationalist writers, non myth-making writers, writers who write against the grain, are like 
subjected peoples living under colonial rule. How they use the language of oppression is important, how they mask and masquerade, relying on that interpretive community, that affiliative reception-group which would understand how borders are crossed in universal terms. Modernity challenges the writer to discard melancholic memories, to take a positive attitude towards progress. But writers of spleen, caught in a contradiction, writers whom I call hybrid writers because of these contradictions, rely not only on the skills of perceptive literary critics, but on their own homelessness. Home is not a space, but a borderless time. There is no authentic position, given that representations of lived experience are always unstable. Resisting the comfort of the production of national mythologies, the comforts of home, they employ their melancholic memory, which is inert to begin with, and energise it by taking on shifting identities which grant creative movement. There is only, as Maurice Blanchot called it, a false certitude of being. ${ }^{26}$ What is produced is an acknowledgement of uncertainty, an aesthetics of insecurity along with linguistic creativity, major risk-taking and speculation ... the very things Kierkegaard expressed in 1848. Again, to quote Eric Wilson:

"With no more melancholics, we would live in a world in which everyone simply accepted the status quo, in which everyone would simply be content with the given." 27

Though I don't agree with him when he says "We don inauthenticity as a mask, a disguise to protect us from the abyss [of melancholy]." ${ }^{28}$ We don the mask, I think, to move blindly towards the edge, away from the all-consuming past. History is now. The melancholic hybrid, who was fed by a nostalgic past is now more attuned to future mourning through thinking. Because identity keeps coming back as an aggression, the cosmopolitan, the hybrid, the polyphonic writer, are all too clearly aware that identity is the ultimate inauthenticity. The melancholic hybrid is the canary in the mine. Its song is life. What is dozing in its language is death, the awareness of which may be recovered by snatching off the mask at the last minute to gaze at the river Lethe below. Melancholy is an antiquity that resists the forgetful destruction in the future which demolishes art. Writing therefore, is an act of will and representation. Moved by exaggeration, the melancholic haunts the world with non-consoling fictions, but not before miming society's conventions. The world to come is never actually encountered, since wise melancholics, as Montaigne advised, keep their souls at the back of the shop, distrusting that side of the imagination which leads to madness.

\footnotetext{
${ }^{26}$ Blanchot, L'espace littéraire, p. 205.

27 Wilson, The Australian.

${ }^{28}$ Wilson.
} 
But do we still have the skills of language and the time for such reflection, which I would call a non-revolutionary response to grievance? Do we still believe in such non-consoling fictions, which are most efficiently expressed in a literary métissage which is not a production of pastiche but a troubled making?

I thought about all this last year on my way to my mother's funeral. I had already predicted her death and a year before, had sent out notices to friends and acquaintances saying I was in mourning and could not possibly give a speech on melancholy. Strangely for my friends, my mother died twice. For me though, I was more prepared for the reality because she had already survived a literary death. She was already living in time and not in space. As I drove, I heard the clear notes of bell-birds, sounding like clinking bottles. The scraping of cicadas sent coded messages through the electric air. I drove another hundred kilometers following the cats-eyes, those reflectors fastened onto the centre of the road. In ancient China, space and time were interwoven. Well before Einstein, the Chinese discovered that space and time were unified in the motion of matter. There was even a saying that time could be read in the eyes of a cat crossing a road. This hyperbole is filled with an elegant frivolity. In reflection, do we not see further in the dark? In seeing further, do we not return to ourselves in death? Returning to my sister's house after my mother's funeral, I noticed a feather duster on the piano. It was one of those they used in Hong Kong, made out of a real rooster's feathers. Under Australia's strict quarantine laws, I didn't know how it got into the country. I asked my sister. She said it was probably a home-grown rooster. Well, there you have it. My mother was dusting off the past. Perhaps it is the home-duty of writing to mourn it before it is lost. 